\title{
Australian Federalism's Impact on Energy Efficiency Policy
}

\author{
Andrew Wear and Phil Harrington
}

The Australian constitution makes no mention of energy or environmental matters. Hence the States have assumed responsibility for developing and implementing energy policy. Yet the need for efficient, large-scale markets, together with Australia's international obligations, demands that a national approach be adopted.

Australia's eight main jurisdictions have acted creatively and cooperatively to deal with these constitutional difficulties. The National Appliance and Equipment Energy Efficiency Program is a successful labelling and standards program that will result in greenhouse savings of 81Mt of $\mathrm{CO}_{2}$ equivalent between 2000 and 2015 at a net economic benefit to the economy.

Yet the complex federal structure is clearly hampering the program's ability to achieve maximum impact, delaying implementation and resulting in confusion for industry. The net result is that greenhouse gas abatement opportunities are forgone and opportunities for greater economy-wide efficiency lost. A more efficient federal system or the introduction of Commonwealth energy efficiency legislation would allow these economywide efficiencies to be captured.

\section{Introduction}

This paper focuses on the National Appliance and Equipment Energy Efficiency Program (NAEEEP) as a case study illustrating the practical effect of federalism on energy policy.

The NAEEEP, which is a joint Commonwealth, State and Territory government program, has proven to be an extraordinarily successful program. Its activities have achieved substantial greenhouse gas emission reductions at a net benefit to the economy. Indeed, it is the most cost-effective greenhouse gas abatement program in existence. Yet it is clear that still further gains are possible.

Furthermore, the role of Australia's federal structure in the NAEEEP's success is not immediately apparent. Can the success of the program be attributed to the program's federal structure, or has the success occurred despite it? The answers to this question point not only to matters specific to Australia's energy policy, but rather also hint at the health of Australian federalism more generally.

\section{Background}

The NAEEEP's activities consist of regulatory and voluntary initiatives and primarily involve labelling and minimum energy performance standards. 


\section{Labelling}

Labelling of appliances empowers consumers through the provision of the information they need to take energy efficiency into account when purchasing a new appliance. The provision of energy efficiency information ensures a healthy, competitive appliance market, where purchasers are able to consider whole-of-life costs for the appliance, not just the purchase price.

The Energy Star scheme enables consumers to identify products meeting a minimum level of energy efficiency by looking for the blue and green endorsement label. Because it is a voluntary scheme, it is not supported by legislation or regulation. Energy Star labels are currently found on computers, printers, faxes and photocopiers. In 2000 it was agreed to expand the scheme to include home entertainment equipment such as televisions, video cassette recorders, digital video disk players and home stereos (National Appliance and Equipment Energy Efficiency Committee 2001a).

By contrast, the Energy Rating scheme involves a mandatory rating label, which informs consumers of the energy consumption of the appliance and awards the appliance a rating of between one and six stars. Because it is a mandatory label, is dependent on supporting legislation and regulations. ${ }^{1}$ The label must be displayed on all refrigerators, freezers, dishwashers, washing machines, clothes dryers and air conditioners up to $7.5 \mathrm{~kW}$ (National Appliance and Equipment Energy Efficiency Committee 2000b).

\section{Minimum Energy Performance Standards (MEPS)}

There are inevitably some areas of the appliance market where labelling will not work, such as where a purchaser is not the user of the product and is hence unconcerned with energy costs. MEPS intervene where this split-incentive exists, or where it can be demonstrated that economic and environmental gains can be made, ensuring that all appliances meet a mandated minimum energy efficiency level.

MEPS currently apply to domestic refrigerators, domestic freezers and domestic electric mains pressure storage water heaters. From 1 October 2001 MEPS will also apply to electric motors and packaged air conditioners (National Appliance and Equipment Energy Efficiency Committee 2001a).

There are plans to significantly expand the MEPS program to include inter alia lighting ballasts, commercial refrigeration, distribution transformers and domestic electric lowpressure water heaters. Furthermore, more stringent standards will also be introduced for domestic refrigerators/freezers and domestic electric mains pressure storage water heaters (National Appliance and Equipment Energy Efficiency Committee 2001b).

\footnotetext{
${ }^{1}$ Electricity Act 1945 (WA), Electricity Act 1994 (Qld), Electricity Safety Act 1945 (NSW), Electricity Safety Act 1998 (Vic), Electrical Products Act 2000 (SA), Electricity (Energy Efficiency Labelling) Regulations 1997 (WA), Electricity (Electrical Articles) Regulation 1994 (Qld), Electricity Safety (Equipment Efficiency) Regulations 1999 (NSW), Electricity Safety (Equipment Efficiency) Regulations 1999 (Vic), Electrical Products Regulations 1997 (SA)
} 


\section{The program's successes}

It is estimated that the mandatory programs that form part of the NAEEEP will reduce greenhouse gas emissions by a total of 81 million tonnes of carbon dioxide equivalent ( $\mathrm{Mt} \mathrm{CO}_{2}$-e) over the period 2000-2015. The average impact during the Kyoto Protocol Commitment period from 2008 to 2012 is estimated to be about 7.2 $\mathrm{Mt} \mathrm{CO}_{2}$-e per annum reduction below business as usual. By 2015 the impact is projected to reach $10.9 \mathrm{Mt}$ $\mathrm{CO}_{2}$-e per annum (National Appliance and Equipment Energy Efficiency Committee 2000a).

Yet the projected benefits stand in marked contrast to the benefits achieved to date. Between late 1986 (when mandatory appliance labelling commenced in the first state) and 2000, the program has reduced greenhouse gas emissions by approximately $5 \mathrm{Mt}$ CO2-e below business as usual (National Appliance and Equipment Energy Efficiency Committee 2001a). The program has got off to a slow start.

It has been shown that every tonne saved will provide a net benefit to the economy. For those components of the program for which complete economic modelling has been carried out, this benefit is estimated to be $\$ 31$ per tonne. At a 10 per cent discount rate, the benefit/cost ratio for this group of products is 2.4. The net benefit to the economy and to energy users - is more than $\$ 1.3$ billion (National Appliance and Equipment Energy Efficiency Committee 2000a). This means higher purchase prices for energy efficient products are well and truly offset by the lower operating costs of those products. Furthermore, the figures quoted above do not incorporate the cost of greenhouse gas and other environmental externalities and the costing of these externalities would greatly enhance the benefit/cost ratio and net benefit to the economy.

The NAEEEP is without doubt the most cost-effective greenhouse gas abatement program currently being implemented in Australia. Not only is the program cost effective from an economy-wide perspective, it also extraordinarily cost-effective fiscally. In his 1997 package of greenhouse response measures, Prime Minister Howard committed \$4.4million to the program over five years (Howard 1997). Even allowing for the contribution of the States to the program, the annual operating costs of the NAEEEP are well under \$2 million.

\section{More to gain}

While Australia currently has MEPS on two product categories, there is scope for substantial expansion. For example, Canada has MEPS on 28 product categories (International Energy Agency 2000).

The Commonwealth Office of Regulation Review vets and reviews regulations to ensure that they do not 'impose undue costs on business and the community.' Regulations may thus proceed if a regulatory impact statement reveals that the regulations will produce no net detriment to the Australian economy (Productivity Commission 2000). As NAEEEP regulations thus far have benefited the economy to the tune of \$31 per tonne of carbon dioxide equivalent abated (National Appliance and Equipment Energy Efficiency Committee 2000a) there is extraordinary scope to substantially expand regulation of the appliance and equipment industry up to the point where there is no net cost to the 
economy. This would enable the capture of enormous low-cost greenhouse abatement potential.

If the cost of greenhouse gas externalities were incorporated into regulatory impact statement, there would be even more scope to regulate for energy efficiency. However, in the absence of a market for carbon, attaching a price to greenhouse gas emissions is a difficult - though not impossible - hurdle to overcome.

\section{A national approach}

The Commonwealth Constitution provides that all jurisdiction lies with the States unless a provision in section 51 provides otherwise. As there is no provision explicitly vesting power in the Commonwealth to regulate energy or the environment, responsibility for energy efficiency falls by default to the states (see Saunders 1996).

Despite these Constitutional provisions, modern circumstances demand that a national approach is taken to energy efficiency policy. International law binds the Commonwealth, not the states, and hence it is the Commonwealth that has responsibility for meeting obligations resulting from ratification of international treaties. Further, it is inefficient and cumbersome for multinational and national manufacturers and retailers to have to comply with different regulations in eight or more jurisdictions.

By and large, Commonwealth, State and Territory Governments have managed to work cooperatively and creatively to develop a national policy framework. While this approach has largely been successful, it is clear that the ad-hoc federal structure that has evolved is neither optimal nor appropriate.

\section{Decision-making structure}

The decision-making structure overseeing the NAEEEP is extremely complex, long and involved. It requires a consensus decision by the ten jurisdictions comprising State, Territory, Commonwealth and New Zealand Governments. This decision-making structure is linked to the funding structure, which sees the Commonwealth contribute 50 per cent of funding and the states and territories the other 50 per cent.

This structure has at its roots the Hawke government's 1990 commitment to a new style of federalism, better able to respond to the cross-jurisdictional nature of many environmental problems. Hawke intended that cooperation between the jurisdictions would take the place of attempts by the Commonwealth to coerce the states and territories (see Holland 1996 and Lynch and Galligan 1996). This resulted in the formation of the Council of Australian Governments (CoAG) and associated ministerial councils responsible for specific policy areas.

The Australian and New Zealand Minerals and Energy Council (ANZMEC) that was established as a part of this process has ultimate responsibility for the NAEEEP. Three subordinate levels of committees consisting of officials from each jurisdiction advise ANZMEC. The National Appliance and Equipment Energy Efficiency Committee (NAEEEC) has direct responsibility for implementing the NAEEEP. NAEEEC reports to the ANZMEC Energy Management Task Force (EMTF) which in turn reports to the 
ANZMEC Standing Committee of officials (SCO) (National Appliance and Equipment Energy Efficiency Committee 1999). The requirement to obtain consensus at each level of decision means that obtaining a final decision is often a long and frustrating process.

The NAEEEP consists of both regulatory and voluntary programs. However decisionmaking structure governing the program is premised on the assumption that the program is regulatory. The involvement of state/territory governments is essential as regulations introduced and implemented at the state/territory level. Yet since the regulatory and voluntary aspects are managed as one program, the voluntary programs are largely forced through the same decision-making hoops, despite the absence of any necessity to introduce regulations.

Before regulations are introduced, each state or territory is required to undertake a regulatory impact statement (RIS) and other regulatory assessment processes. Although the CoAG process provides that the Commonwealth Office of Regulation Review may conduct the RIS on behalf of the other jurisdictions, this does not often occur. The RIS process, with the engagement of consultants, and lengthy public consultation periods, mean that the swift introduction of regulations is a near-impossible task.

A further complicating factor is the involvement of New Zealand in the process. The Trans Tasman Mutual Recognition Agreement (TTMRA) demands that there be no market barriers between Australia and New Zealand. Consequently, the New Zealand government must agree to any energy efficiency regulations before they may be implemented. If no agreement can be reached, each Australian jurisdiction (ie all 9) needs to legislate for an exemption to the TTMRA. This is a long and tedious process. Political considerations have made agreement between Australian and New Zealand governments difficult in the past and it has been necessary to seek such an exemption. However the recent election of a Labour/Green coalition government which supports regulation for energy efficiency labelling and standards means it is likely a TTMRA exemption will become unnecessary (National Appliance and Equipment Energy Efficiency Committee 2001a).

\section{Federalism's contribution to energy efficiency}

An advantage to the broad involvement of jurisdictions in the program is that there is a wider leadership pool from which to draw. With nine Ministers of various political persuasions and energy levels it is more likely that at least one jurisdiction will take on a leadership role, shepherding new projects through the exhaustive committee process.

For example, Victoria and NSW first proposed the Energy Rating scheme in the late 1970s. Mandatory labelling began in these states in the late 1980s, eventually leading to agreement in 1992 to establish a national scheme (National Appliance and Equipment Energy Efficiency Committee 2001c).

While the Mutual Recognition Act 1992 and National Competition Policy agreements (see National Competition Council 1995) now largely impede attempts by states to unilaterally introduce regulations applying to goods traded nationally, there is still ample scope for states to take principal carriage of a project and work with other jurisdictions to 
establish a national scheme under the federal structure. However, in recent years this has not been a common occurrence.

Another advantage to the federal structure is that it invariably leads to a bipartisan approach to policy development. With nine Australian jurisdictions represented, there is invariably cross-party involvement in the policy development process. Hence there is little opportunity for opposition parties to gain politically through attacking the program, as their counterparts in other jurisdictions are inevitably involved. It is probably wise not to overlook the significance of this point.

\section{Problems}

Obtaining approvals from the various committees is extraordinarily time-consuming. There is a six-month interval between meetings of NAEEEC, EMTF, ANZMEC SCO and ANZMEC. As a result, prompt decisions are difficult to obtain and thus the program lacks a degree of responsiveness. These delays are one reason the stringency levels of Australian MEPS are behind the levels adopted by our major trading partners. Yet relations between government and industry have arguably been a greater contributor to delay than the attainment of agreement from jurisdictions. For example, lack of an agreed process between industry and government meant the first refrigerator MEPS took effect in 1999. Established after a cost-benefit study in 1993, the proposed MEPS levels were originally modelled to commence by the end of 1996 (Holt et al. 2000). This sort of delay means that substantial energy and greenhouse gas savings are forgone. However, as more MEPS are have been proposed and introduced, an improved process has been agreed and this should enhance the process considerably (Holt et al. 2000).

Yet, the complexity resulting from multiple decision points and multiple jurisdictions undoubtedly means there is scope for more to go wrong. For example, given New Zealand's past reluctance to introduce energy efficiency labels and standards, it was necessary to for each state to enact an amendment to that state's TTMRA Act. This would prevent non-compliant products being sold in Australia after entering the country via New Zealand. However, as at March 2001, Queensland had failed to properly enact the appropriate legislation, thus allowing non-compliant products to enter the Australian market through that state. In this instance, one error by one jurisdiction had the potential to undermine the effectiveness of the entire program.

One of the more fundamental problems with the current federal structure is the length of time it takes to introduce legislative or regulatory change. At the time of writing, nine years after a CoAG decision to establish a regime of nationally consistent legislation, both the Australian Capital Territory (ACT) and Tasmania are yet to introduce legislation into their respective parliaments. Hence, MEPS and labelling requirements do not apply in these jurisdictions. Under the Mutual Recognition Act 1992 all products manufactured or imported into these jurisdictions are exempt from MEPS and labelling requirements if on-sold into other jurisdictions. Hence, the delay by the ACT and Tasmania is another instance where the complexity of the federal structure has the potential to undermine the entire program. Fortunately for the program, neither of these jurisdictions has a sizeable manufacturing base, a major international airport or a substantial port. 
Once appropriate legislation is in place, regulations have inevitably been introduced into each State and Territory jurisdiction in differing forms. This is due to differences in the supporting legislation, the conducting of separate Regulatory Impact Statements and the drafting process itself. Manufacturers are thus able to choose the jurisdiction in which they register their appliances. With different regulations in each state, manufacturers have been able to engage in 'regulator shopping', seeking out the jurisdiction with the most favourable registration conditions.

Furthermore, regulators are able to interpret the applicable Australian Standards (to which the regulations refer) and make a decision as they see appropriate. This has been further incentive for manufacturers to 'shop around' and seek out the regulator they feel will give a decision most in their favour. This problem has largely, though not entirely, resolved through increased cooperation and communication between regulators (National Appliance and Equipment Energy Efficiency Committee 2000c).

A further problem with overseeing the regulatory arrangements underpinning the program is that there are currently only four states with a regulatory authority. Victoria, New South Wales, Queensland and South Australia all process product registrations and ensure compliance with the regulations. Other states and territories have introduced legislation and regulations yet do not currently have any authority or agency able to ensure compliance.

Probably the most fundamental difficulty with the federal structure overseeing the program is that there is no accountable Minister, and hence the structure subverts values underlying the Westminster system of government upon which Australian government is based. Responsibility, rather than being with an accountable Minister is diffused through a committee of Ministers.

This diffusion of power ensures that it is difficult to market the program's successes. No single Minister or no single government may claim credit for the program. More fundamentally, there is no responsible Minister should something go wrong. The bipartisan committee approach effectively means that all opposition is coopted. Hence the activities and administration of the program are largely unscrutinised.

Emissions from the stationary energy sector accounted for 56.7 per cent of Australia's greenhouse gas emissions in 1999 (Australian Greenhouse Office 2001). With the Commonwealth having the responsibility under international law to minimise greenhouse gas emissions, the lack of ability to regulate the largest emitting sector is somewhat perplexing.

\section{Consequences}

It is clear that the range of products covered by MEPS so far is less than ideal, that the implementation of MEPS has been delayed and that an inadequate compliance system is in place. A complex federal structure must take at least some of the blame for this suboptimal outcome.

The result is that Australia is not taking full advantage of a cost-effective greenhouse gas abatement program. While substantial abatement has been achieved, sizeable savings have also been forgone. Cost-effective energy savings and emission reductions that are 
not captured now will have to be made up through more costly measures later, as pressure to reduce greenhouse gas emissions gains momentum. This will invariably impact adversely upon the Australian economy. Further, since every tonne of greenhouse gas emissions saved through energy efficiency benefits the economy, every tonne of emissions that is not saved inevitably impacts negatively upon the economy, through productivity gains forgone.

\section{Solutions}

\section{Improved federal approach}

Within the confines of a federal structure, there is significant scope to reform policy development and implementation approaches.

In 1999, the MEPS process was streamlined. The revised process should see new product MEPS introduced within a maximum of five years from the date of publicly commencing the assessment process. In addition it is proposed that the most stringent regulatory standards imposed by our trading partners be adopted, subject to a number of conditions. The new process is formulated with the goal that the MEPS process should be a cooperative pact between government and industry, avoiding the delays and conflict of the immediate past (Holt et al 2000). Significant improvement is already apparent (National Appliance and Equipment Energy Efficiency Committee 2001a and 2001b).

To ensure consistency between jurisdictions, avoiding the confusion of differing acts and regulations, it would be possible for states and territories to enact legislation referencing another state's legislation. This would result in the exact words being replicated in each jurisdiction.

There are numerous Council of Australian Governments (CoAG) precedents for doing so. For example, in the lead up to industry deregulation and privatisation, Australian jurisdictions agreed at CoAG level on arrangements concerning gas pipelines access. The result was the Gas Pipeline Access Act 1998. South Australia enacted legislation in accordance with the CoAG agreement. All other states and territories then introduced legislation simply stating that their state would be regulated by the South Australian Act. South Australian regulations attached to the South Australian legislation would thus be enforced in all states and hence regulation across all states would be consistent.

For voluntary programs not supported by legislation or regulation, it would be far simpler and more efficient to simply remove them from the federal structure. There is no justification for forcing voluntary programs through four decision points, as is required by the mandatory programs.

Voluntary programs are traditionally communication activities targeted at the community and states and territory government agencies have established energy advisory centres that act as contact points with the community. For this reason, it is sometimes argued that the involvement of states and territories in voluntary programs is essential. Even given this, consultation, communication or perhaps even contract may prove to be a more effective and efficient means of delivering the programs than the existing process has been. 


\section{Commonwealth legislation}

Rather than seeking to reform the existing federal structure, it may be more straightforward and more efficient to simply introduce Commonwealth legislation allowing the energy efficiency of appliances and equipment to be regulated by the Commonwealth. This has the capacity to resolve the decision-making and implementation difficulties faced by the federal structure. The efficiency gains to be made through consolidating eight pieces of legislation into one would be significant. It would be necessary to obtain the support of only one parliament, not eight, for the introduction of or changes to legislation. And it would be necessary to obtain the support of only one minister, not nine, for the introduction of, or changes to, regulations. Finally, Commonwealth legislation would ensure that laws regulating energy efficiency are consistent across the country and that an effective compliance mechanism with universal coverage could be put in place.

This approach clearly has much third party support. In a submission to the Senate Environment, Communications, Information Technology and the Arts References Committee report into Commonwealth Environment powers the Humane Society International Inc argued that the Commonwealth should provide national legislation on key environmental issues of national interest such as greenhouse (Senate References Committee 1999). The Minerals Council of Australia, while not necessarily arguing for Commonwealth legislation, contended that the key considerations for the Commonwealth when considering a more consistent national response are “...improving efficiency of government processes, minimising distortions due to different approaches in different jurisdictions, reducing overlaps and duplication, reducing disputes between level of government...” (Senate References Committee 1999, 3.80). Commonwealth energy efficiency legislation would address all of these concerns.

The Australian Competition and Consumer Commission believes that Commonwealth legislation would contribute to a resolution of most of the difficulties faced by the NAEEEP. In its in 'Report on Enforcement Strategies associated with the National Appliance and Equipment Energy Efficiency Program’ it stated that:

The ACCC believes that Commonwealth legislation can play a beneficial role in helping to overcome some of the difficulties that have occurred when there is only State-based legislation in relation to issues that have national implications. (Australian Competition and Consumer Commission 2000, p 19-20)

There can be no doubt that the Commonwealth does have the power to introduce Commonwealth legislation (see Saunders 1996). As the Senate enquiry into Commonwealth Environment Powers concluded, "the Commonwealth Government has the Constitutional power to regulate, including by legislation, most, if not all, matters of major environmental significance anywhere within the territory of Australia” (Senate References Committee 1999, 2.19). It consequently recommended that:

The Commonwealth should exercise a leadership role in the protection and improvement of the Australian environment. This role should be supported by the 
unsparing use of all Constitutional power available to the Commonwealth to act in the field of the environment. (Senate References Committee 1999, 3.7)

Provisions relevant to the regulation of appliances and equipment for energy efficiency include: the interstate and overseas trade and commerce power (s. 51(i)); the Commonwealth corporations power (s. 51(xx)); the reference from State governments power (s. 51(xxxvii); and the Commonwealth territories power (s. 122).

Most importantly, the external affairs power (s. 51(xxix)) allows the Commonwealth to regulate if necessary to give effect to treaty to which Australia is a party. The Franklin Dam case established that the external affairs power extends to the implementation of any bona fide international treaty obligations to which Australia is a party. The only requirement is that there be proportionality in the mechanisms adopted by Parliament to implement its obligations.

The United Nations Framework Convention on Climate Change, to which Australia became a party in 1992 provides that developed countries shall 'adopt national policies and take corresponding measures on the mitigation of climate change, by limiting its anthropogenic emissions of greenhouse gases...' (United Nations 1992). Given that the stationary energy sector accounts for 56.7 per cent of greenhouse gas emissions (Australian Greenhouse Office 2001), the Commonwealth should have little trouble satisfying the proportionality requirement with respect to Commonwealth energy efficiency legislation.

A significant effect of the introduction of Commonwealth energy efficiency legislation would be that responsibility for energy efficiency programs would no longer be diffuse. A single Minister would be responsible and accountable for the success or failure of the programs. As such, it is likely that energy efficiency programs would become more politicised than they are at present. Opposition parties and state/territory government would no longer be coopted to the program and as such would be freed up to scrutinise or criticise the programs. Depending on the nature of the scrutiny, this could either lead to acceleration or deceleration of energy efficiency activity. However, given the positive impacts of energy efficiency on both the economy and the environment, it is more likely that increased scrutiny would lead to calls for acceleration of the program.

Naturally, introduction of such legislation would involve significant change in Commonwealth-State-Territory relations in this area. The Commonwealth would be responsible for financing the program's implementation as well as its enforcement. The regulatory states would lose a source of income in the form of product registration fees. Although relatively straightforward to resolve through negotiated changes in Commonwealth-State fiscal arrangements, is likely to result in short-term disquiet. Like all change, it will require the Government to keep in mind the importance of good public policy, and to demonstrate political will.

\section{Conclusion}

The National Appliance and Equipment Energy Efficiency Program is an extraordinarily cost-effective greenhouse gas abatement program, achieving substantial greenhouse gas savings at net benefit to the economy. However despite its success, the program is being 
constrained by a complex federal structure. The convoluted process involving

Commonwealth, State and Territory governments has resulted in inordinate delays, inconsistent regulations and an ineffective compliance mechanism.

This inefficiency of process has meant that the opportunity to capture even greater energy and greenhouse savings has been forgone. As each tonne of greenhouse gas saved as a result of the program results in improved efficiencies at the economy-wide level, the retarded progress of the program will impact negatively on the economy.

There is thus an urgent imperative to reform the decision-making and implementation process and this must be activated at the political level. Reform should involve either a streamlining of the existing federal structure or a more radical response involving the introduction of Commonwealth energy efficiency legislation. Delay in instituting such reform means that very real social, economic and environmental costs accrue to the Australian and international community.

\section{Postscript}

Subsequent to the completion of this paper, the Council of Australian Governments met on 8 June 2001 and agreed to establish a new 'Ministerial Council on Energy'. This decision was motivated by a desire to ensure that Governments 'provide effective policy leadership to meet the opportunities and challenges facing the energy sector' (CoAG 2001, p 1). The proposed council apparently differs from ANZMEC only in its exclusion of New Zealand.

It is understood that the operations of NAEEEC will be unaffected. Consequently, it would appear that this CoAG decision does nothing to simplify the complex decisionmaking structure constraining Australia's ability to take full advantage of an extremely cost-effective greenhouse gas abatement measure. The issues identified in this paper remain unresolved.

\section{References}

Australian Competition and Consumer Commission. 2000. Report on Enforcement Strategies Associated with the National Appliance and Equipment Energy Efficiency Program. Australian Competition and Consumer Commission, Canberra.

Australian Greenhouse Office. 2001. National Greenhouse Gas Inventory 1999. Commonwealth of Australia, Canberra.

Council of Australian Governments. 2001. Council of Australian Governments Meeting 8 June 2001: Communique, Commonwealth of Australia, Canberra (http://www.pmc.gov.au/docs/coag080601.cfm)

Energy Efficient Strategies. 2001. Greening Whitegoods: A Report into the Energy Efficiency Trends of Major Household Appliances in Australia from 1993 to 1999. Commonwealth of Australia, Canberra. 
Holland, K.M. 1996. Introduction, in Holland, K.M., Morton, F.L. and Galligan, B. Federalism and the Environment: Environmental Policymaking in Australia, Canada, and the United States. Greenwood Press, London.

Holt, S., Marker, A. and Harrington, L. 2000. The Design of a Codes and Standards Program: The Australian Experience in Efficiency and Sustainability: Proceedings of the 2000 ACEEE Summer Study on Energy Efficiency in Buildings. Volume 9. American Council for an Energy Efficient Economy, Washington D.C.

Howard, J.W. 1997. Safeguarding the Future: Australia's Response to Climate Change Ministerial Statement. Department of the Parliamentary Library, Canberra.

International Energy Agency. 2000. Energy Labels \& Standards. International Energy Agency, Paris.

Kellow, A. 1996. Thinking Globally and Acting Federally: Intergovernmental Relations and Environmental Protection in Australia, in Holland, K.M., Morton, F.L. and Galligan, B. Federalism and the Environment: Environmental Policymaking in Australia, Canada, and the United States. Greenwood Press, London.

Lynch, G. and Galligan, B. 1996. Environmental Policymaking in Australia: The Role of the Courts, in Holland, K.M., Morton, F.L. and Galligan, B. Federalism and the Environment: Environmental Policymaking in Australia, Canada, and the United States. Greenwood Press, London.

National Appliance and Equipment Energy Efficiency Committee. 1999. National Appliance and Equipment Energy Efficiency Program. Commonwealth of Australia, Canberra.

National Appliance and Equipment Energy Efficiency Committee. 2000a. Projected Combined Impacts from an Extended and Enhanced Program. Commonwealth of Australia, Canberra.

National Appliance and Equipment Energy Efficiency Committee. 2000b. Your Guide to the Revised Appliance Energy Rating Label. Commonwealth of Australia, Canberra.

National Appliance and Equipment Energy Efficiency Committee. 2000c. Administrative Guidelines for the Appliance and Equipment Energy Efficiency Program of Mandatory Labelling and Minimum Energy Performance Standards for Appliances. Commonwealth of Australia, Canberra

National Appliance and Equipment Energy Efficiency Committee. 2001a. Achievements 2000. Commonwealth of Australia, Canberra.

National Appliance and Equipment Energy Efficiency Committee. 2001b. Future Directions 2001-2004. Commonwealth of Australia, Canberra.

National Appliance and Equipment Energy Efficiency Committee. 2001c. Background and History to the Labelling Program. Commonwealth of Australia, Canberra (http://www.energyrating.gov.au/consumers/history.html)

National Competition Council. 1995. National Competition Policy Agreements, Commonwealth of Australia, Canberra (http://www.ncc.gov.au/nationalcompet/agreements) 
Productivity Commission. 2000. Regulation and its Review 1999-2000. Commonwealth of Australia, Canberra.

Saunders, S. 1996. The Constitutional Division of Powers with Respect to the Environment in Australia, in Holland, K.M., Morton, F.L. and Galligan, B. Federalism and the Environment: Environmental Policymaking in Australia, Canada, and the United States. Greenwood Press, London.

Senate Environment, Communications, Information Technology and the Arts References Committee (Senate References Committee). 1999. Commonwealth Environment Powers Inquiry. Commonwealth of Australia, Canberra.

Senate Environment, Communications, Information Technology and the Arts References Committee (Senate References Committee). 2000. The Heat is On: Australia's Greenhouse Future. Commonwealth of Australia, Canberra.

United Nations. 1992. United Nations Framework Convention on Climate Change, United Nations, Bonn

\section{Court Cases}

Commonwealth v Tasmania (Franklin Dam case) (1983) Australian Law Reports 625 
Page 14 


\section{University Library}

\section{- M M I N E R VA A gateway to Melbourne's research publications}

Minerva Access is the Institutional Repository of The University of Melbourne

Author/s:

Wear, Andrew;Harrington, Phil

Title:

Australian federalism's impact on energy efficiency policy

Date:

2002

Citation:

Wear, A. \& Harrington, P. (2002). Australian federalism's impact on energy efficiency policy. Australian Journal of Environmental Management, 9(1), 37-44.

Publication Status:

Published

Persistent Link:

http://hdl.handle.net/11343/33495 